\title{
KAJIAN PSIKOLINGUISTIK TERHADAP BENTUK DAN FUNGSI LINGUAL LATAH: STUDI KASUS WARGA MEDAN
}

\section{PSYCHOLINGUISTICS STUDY ON HYPEREKPLEXIA OF FORM AND FUNCTION: CASE STUDY ON MEDAN CITIZENS}

\author{
Andi Saputra Tanjung, Gustianingsih, Syahron Lubis \\ Program Studi Linguistik Program Pascasarjana \\ Fakultas IImu Budaya, Universitas Sumatera Utara \\ Email:bayotanjung@ymail.com, 081314619798 \\ Naskah diterima tanggal 12 Desember 2018 \\ Naskah direvisi terakhir tanggal 6 September 2019
}

\begin{abstract}
hyperstartle syndrome is interesting to research using psycholinguistic study. This research electorates the linguistic form of language of the residents in Jalan Garu III, Medan Amplas, Kota Medan. The qualitative data are words and sentences that used in behavior in Jalan Garu III, Medan Amplas, Kota Medan. The result of the research is the description of the linguistic forms of talkative behavior in the form of words and sentences, including: (1) coprolalia talkative behavior, (2) ecolalia talkative behavior, (3) autoecolalia talkative behavior, (4) automatic obedience talkative behavior. This research discovers some language functions: (1) self expression, (2) interactional function, and (3) personal function.
\end{abstract}

Key words: talkative language, kind of talkative, psycholinguistic, language functions.

\begin{abstract}
Abstrak
Perilaku latah menarik untuk diteliti dengan kajian psikolinguistik. Penelitian ini mendeskripsikan bentuk lingual bahasa latah pada tiga warga Jalan Garu III, Medan Amplas, Kota Medan dan faktor penyebab warga beperilaku latah. Data kualitatif berupa kata dan kalimat pada perilaku latah yang ada di Jalan Garu III, Medan Amplas, Kota Medan. Hasil penelitian ini terdapat deskripsi bentuk-bentuk lingual perilaku latah berupa kata dan kalimat, meliputi: (1) perilaku latah Koprolalia, (2) perilaku latah Ekolalia, (3) perilaku latah Auto Ekolalia, dan (4) perilaku latah Automatic Obidience. Hasil penelitian ini juga fungsi bahasa yang dikemukakan oleh para ahli yang dikaitkan dengan bahasa orang latah, yaitu (1) fungsi ekspresi diri, (2) fungsi interaksi (the interactional function), dan (3) fungsi personal (the personal function).
\end{abstract}

Kata Kunci: bahasa latah, jenis latah, psikolinguistik, fungsi bahasa.

\section{PENDAHULUAN}

Setiap manusia mempergunakan bahasa sebagai alat komunikasi. Dalam kesehariannya manusia tidak lepas dari bahasa. Manusia sebagai makhluk sosial perlu berinteraksi atau berkomunikasi dengan manusia lain. Interaksi atau komunikasi akan berjalan dengan baik jika menggunakan bahasa. Dengan demikian, bahasa mempunyai peranan penting dalam kehidupan manusia.

Bahasa merupakan suatu media penyampaian informasi, ide atau gagasan melalui bunyi-bunyi atau lambang-lambang yang terucap dari alat ucap manusia. Bahasa selain digunakan untuk berkomunikasi dengan sesama manusia juga dipergunakan sebagai alat untuk mengekspresikan diri. 
Pernyataan tersebut sesuai dengan pendapat Mustakim (1994) bahwa bahasa dapat digunakan sebagai alat untuk berekspresi atau untuk mengungkapkan segala sesuatu yang mengendap dalam batin seseorang, baik berupa gagasan, pikiran, perasaaan, maupun pengalaman yang dimilikinya (hlm. 4).

Keberadaan orang latah mungkin sudah tidak asing lagi atau dianggap umum bagi semua orang. Perilaku latah tersebut bukan suatu yang dianggap aneh lagi. Sebagian orang sudah menganggap perilaku tersebut hal yang biasa, karena perilaku tersebut tidak menimbulkan bahaya malah perilaku ini dianggap sebagai perilaku yang bisa membuat orang tertawa. Dengan demikian, banyak orang menganggap perilaku latah merupakan kejadian yang dianggap sebagai kelucuan, namun dilain sisi, perilaku latah merupakan suatu penyakit, seperti yang dicontohkan pada tiga orang warga Jalan Garu III Medan amplas, Kota Medan.

Pengaruh lingkungan tidak semua memberi dampak yang baik, tetapi juga memberi dampak yang kurang baik bagi perkembangan kebahasaan. Pengaruh yang kurang baik salah satunya yaitu bentuk perilaku latah yang dialami oleh tiga orang warga di Jalan Garu III Medan Amplas, Kota Medan. Bentuk perilaku latah pada warga tersebut adalah bentuk perilaku latah yang berupa bahasa. Bahasa latah muncul akibat adanya sentuhan atau rangsangan. Gejala latah ini merupakan gejala kebahasaan dari orang yang mempunyai perilaku latah yang berupa pengekspresian diri.

Melalui bahasa latah, orang latah bebas mengekspresikan dirinya atau mengungkapkan perasaannya tanpa ada rasa malu sedikitpun. Gejala latah tersebut muncul ketika orang tersebut mendapatkan perhatian lebih atau mendapat rangsangan dari teman. Tanpa sadar penderita latah dengan mudahnya mengeluarkan kata atau kalimat ketika ada seseorang yang secara sengaja maupun tidak sengaja memberi sentuhan atau rangsangan kepada orang latah. Sentuhan pada orang latah biasanya berupa sentuhan pada bagian badan baik secara pelan maupun keras. Ketika orang latah mendapat sentuhan, biasanya orang tersebut akan mengeluarkan kata-kata jorok atau kotor dan bisa juga kata yang didengar oleh orang latah akan diulang baik kata yang diucapkannnya sendiri maupun kata yang diucapkan oleh orang lain.

Berdasarkan fakta yang terjadi di masyarakat, gangguan latah biasanya tumbuh dalam masyarakat terbelakang. Banyak teori yang mengemukakan bahwa penderita latah biasanya adalah orang tua, kaum perempuan, berpendidikan rendah, dan berasal dari kelas ekonomi bawah. Menurut Dardjowidjojo (2005) latah adalah suatu tindak kebahasaan dimana seseorang, waktu terkejut atau dikejutkan, mengeluarkan kata-kata secara spontan dan tidak sadar dengan apa yang dia katakan. Latah mempunyai ciri-ciri sebagai berikut (1) latah hanya terdapat di Asia Tenggara, (2) pelakunya hampir selalu wanita, (3) kata-kata yang dikeluarkan umumnya berkaitan dengan seks atau alat kelamin pria atau jantan dan kalau kejutannya berupa kata, maka orang yang latah juga bisa hanya mengulang kata yang telah disebutkan. Teori mengenai latah menurut beberapa penelitian memang benar. Namun sekarang teori tersebut sudah tidak relevan lagi (hlm. 154). Pada kenyataan yang ada, sekarang banyak sekali remaja yang berpendidikan tinggi baik dari golongan ekonomi bawah maupun menengah ke atas yang mengidap perilaku latah. Jumlah orang latah yang sebagian besar adalah wanita, karena masyarakat wanita terikat dengan peraturan atau norma yang sangat membatasi ruang lingkup mereka (Pamungkas, 1998:18).

Menurut Kaltarina (2013), latah adalah suatu ucapan atau perbuatan yang terungkap secara tak terkendali setelah terjadinya reaksi kaget. Adapun teorinya, latah terbagi menjadi empat yaitu: (1) ekolalia yaitu perilaku latah ini menirukan kata-kata dan kalimat yang diberikan orang lain, (2) koprolalia yaitu perilaku latah ini biasanya mengucapkan kata-kata berupa alat kelamin baik laki-laki maupun perempuan, dan (3) auto ekolalia, yaitu perilaku latah ini biasanya mengulangi kata- 
kata yang diucapkannya sendiri (4) automatic obidience, yaitu perilaku latah ini biasanya melaksanakan perintah secara spontan pada saat terkejut dan ada lagi sekarang seiring dengan berkembangnya zaman, jenis-jenis latah semakin berkembang sesuai dengan peradaban.

Pada penelitian ini, peneliti menggunakan pendekatan psikolinguistik yaitu gabungan dari dua ilmu yaitu psikologi dan linguistik. Menurut Fraisse (dalam Pateda, 1998) psikolinguistik adalah telaah tentang hubungan antara kebutuhankebutuhan kita untuk berekspresi dan berkomunikasi dan benda-benda yang ditawarkan kepada kita melalui bahasa yang dipelajari sejak kecil dan tahap-tahap selanjutnya. Dengan demikian, dalam menelaah bahasa latah pada tiga orang warga Jalan Garu III Medan Amplas, Kota Medan ini penulis menggunakan pendekatan dari segi psikologi, karena pemunculan bahasa latah ada kaitannya dengan tekanan yang dialami oleh seseorang, baik tekanan dari dalam individu maupun tekanan dari luar individu. Selain itu, pemunculan bahasa latah yang biasanya muncul pada saat seorang terkejut perlu dikaji secara lebih mendalam yaitu melalui pendekatan psikologi (hlm. 13).

Berdasarkan perilaku latah tersebut di atas, maka data yang diperoleh pun berupa data perilaku latah yang berupa bahasa yang berbentuk kata dan kalimat. Terkait dengan ruang lingkup penelitian tersebut, maka permasalahan yang akan dibahas dalam penulisan ini sebagai berikut.

1. Apa sajakah bentuk lingual latah pada tiga orang warga Jalan Garu III Medan Amplas, Kota Medan?

2. Apa sajakah fungsi bahasa latah pada tiga orang warga Jalan Garu III Medan Amplas, Kota Medan?

Adapun tujuan yang akan dicapai dalam penelitian ini adalah: (1) Mendeskripsikan dan menjelaskan bentuk lingual latah pada tiga orang warga Jalan Garu III Medan Amplas, Kota Medan; dan (2) Mendeskripsikan dan menjelaskan fungsi bahasa latah pada tiga orang warga Jalan Garu III Medan amplas, Kota Medan.
Hasil penelitian ini dapat diperoleh dua manfaat, yaitu manfaat teoretis dan manfaat praktis. Manfat yang diperoleh dari penelitian ini adalah sebagai berikut.

Adapun manfaat teoretis pada penelitian ini adalah sebagai berikut: (1) Memberikan sumbangsih terhadap perkembangan ilmu pengetahuan, khususnya ilmu bahasa (linguistik). (2) Mengembangkan dan memberi kontribusi pada teori psikolinguistik terutama teori yang berkaitan dengan bahasa latah; dan (3) Memberikan acuan perbandingan serta penyempurnaan bagi penelitian sejenis selanjutnya.

Manfaat praktis penulisan penelitian ini adalah sebagai berikut: (1) Sebagai pertimbangan atau referensi, informasi dan sumbangan pemikiran bagi penelitian selanjutnya yang berkaitan dengan bahsa latah; (2) Bagi mahasiswa yang mendalami bidang linguistik, hasil penelitian ini dapat memberikan hasil kontribusi terhadap materi psikolinguistik secara lebih mendalam; dan (3) Dapat memberikan sumbangan ilmu bagi ilmu kebahasaan, sehingga dapat dipakai sebagai dokumentasi di jurusan program linguistik.

\section{METODE PENELITIAN}

Penelitian ini bertujuan untuk menganalisis dan menjelaskan fenomena bahasa latah. Pada penelitian ini, peneliti menggunakan metode deskriptif kualitatif. Metode kualitatif menurut Moleong (2005) adalah penelitian yang bermaksud memahami fenomena yang dialami oleh subjek penelitian, misalnya perilaku, presepsi, motivasi, tindakan, dan lain-lain, secara holistik dan dengan cara deskripsi dalam bentuk kata-kata dan bahasa, pada suatu konteks khusus yang alamiah dan dengan cara memanfaatkan berbagai metode alamiah (hlm. 6).

Penelitian ini bersifat derskriptif, artinya kerja penelitian ini semata-mata hanya berdasarkan fakta yang ada pada penutur-penuturnya (Sudaryanto 1993: 82). Metode deskriptif dapat digunakan untuk memberikan, menggambarkan, menguraikan, dan menjelaskan data atau objek secara 
formal, objektif, dan faktual (apa adanya) (Arikunto, 1993:310).

Metode yang digunakan dalam teknik penyediaan data ini adalah metode simak. Disebut metode simak atau penyimakan karena pemerolehan data lewat menyimak menggunakan bahasa. Sebagai teknik dasar, peneliti menggunakan teknik sadap dan dilanjutkan dengan teknik lanjutan yaitu teknik simak libat cakap (SLC). Kegiatan meyadap dilakukan dengan melihat dan mengamati informan ketika berbicara dengan peneliti maupun orang ketiga dan orang tersebut memberi rangsangan berupa stimulus. Simak libat cakap maksudnya adalah peneliti berpartisipasi dalam pembicaraan dengan orang latah dan ikut memberi stimulus atau rangsangan tertentu yang diduga dapat memunculkan kata ataupun kalimat. Selain itu, masih ada dua teknik lanjutan dari Sudaryanto (1993:135) yang juga penulis gunakan dalam mengumpulkan data yaitu teknik rekam dan teknik catat. Maksudnya, dalam mengumpulkan data dari informan, penulis pergunakan untuk merekam bentuk-bentuk lingual yang muncul dari informan dan mencatat data-data yang telah dikumpulkan.

Metode yang digunakan dalam teknik analisis data yaitu metode agih. Metode tersebut adalah suatu metode analisis yang alat penentunya merupakan alat dari bahasa itu sendiri (Sudaryanto, 1993). Alat penentu dari metode agih ini merupakan bagian atau unsur suatu bahasa dari objek sasaran penelitian itu sendiri. Metode ini digunakan untuk menganalisis data yaitu berupa kata maupun kalimat yang dihasilkan oleh warga yang mempunyai perilaku latah (hlm. 15).

Dalam analisis data penulis menggunakan metode kualitatif. Menurut Bogdan dan Taylor (dalam Moleong, 1990) metode kualitatif didefinisikan sebagai prosedur penelitian yang menghasilkan data deskriptif, mulai dari kata-kata atau kalimat, juga bisa gerakan tubuh dari orang latah yang perilakunya dapat diamati (hlm. 3).

Teknik pemaparan hasil analisis data pada penelitian ini ada dua macam, yaitu formal dan informal. Pemaparan hasil analisis data yang bersifat formal adalah perumusan analisis dengan lambang-lambang atau tanda-tanda, sedangkan pemaparan informal adalah perumusan analisis dengan kata-kata biasa (Sudaryanto, 1993). Pemaparan hasil analisis data dalam tesis ini dipaparkan dengan menggunakan metode informal, yaitu memaparkan hasil analisis data dengan menggunakan kata-kata biasa tanpa menggunakan tanda atau lambanglambang khusus (hlm. 145).

\section{PEMBAHASAN}

\section{Satuan Lingual Latah Berupa Kata}

Kegiatan bahasa tidak terlepas dari peran sebuah kata, di mana kata-kata tersebut akan disusun menjadi kalimat. Melalui penyusunan setiap kata dengan tepatlah dapat tersusunnya sebuah kalimat yang baik dan efektif. Menurut Finoza (2003), mengungkapkan bahwa "Kata adalah satuan bentuk terkecil dari kalimat yang dapat berdiri sendiri dan mempunyai makna". Jelas apa yang dikemukakan oleh Finoza, bahwa kata merupakan unsur bahasa yang dapat berdiri sendiri dan mempunyai makna tetentu (hlm. 61).

\section{a. Bentuk Lingual Latah Berupa Kata Perilaku Latah Koprolalia}

Bentuk lingual latah berupa kata pada perilaku latah koprolalia adalah perilaku latah ini biasanya mengucapkan kata-kata berupa alat kelamin baik laki-laki maupun perempuan.

Konteks

Tuturan 1:

: Percakapan ini terjadi antara peneliti dengan subjek 1 . Subjek sedang berada di sebuah toko (kedai) pada pagi hari pukul 09.00 WIB. Peneliti menemui subjek kemudian mengajaknya bercakap-cakap.

Pn : Eh, Bu (sambil menyentuh pelan lengan subjek dari belakang) "hai $\mathrm{Bu}$ "

$\mathrm{Su} \quad$ : Eh $i t^{*} l$ (dengan suara pelan dan melambaikan tangan), "buat kaget saja, mau ngapain?" 
Pn : Ini Bu mau beli,

Berdasarkan data lingual tersebut dapat dideskripsikan bahwa bentuk lingual yang dimunculkan oleh subjek 1 dalam percakapan adalah berupa kata. Bentuk lingual yang dimunculkan oleh subjek tersebut dapat diketahui ketika subjek memunculkan bentuk lingual kata $i t * l$ dengan suara pelan. Peneliti tidak menangkap adanya intonasi final yang mengakhiri pemunculan bentuk lingual kata tersebut.

Konteks: Percakapan ini terjadi antara peneliti dengan subjek 2 pada pukul 16.30 WIB. Ketika itu peneliti dan subjek sedang duduk santai di ruang tamu rumah subjek tinggal. Peneliti mendekati subjek dan duduk sambil bercakap-cakap di dekat subjek.

Tuturan 2:

Pn : Biasanya kalau malam apa yang Ibu kerjakan?

$\mathrm{Su}$ : Apa pak?

Pn : Kalau malam biasanya apa saja yang Ibu kerjakan? (dengan pelan menyentuh bagian leher belakang subjek secara sembunyi-sembunyi)

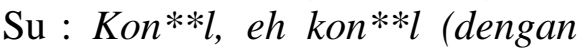
suara pelan dan sambil menggelengkan kepala karena geli sembari memegang mulutnya)

Berdasarkan data tersebut dapat dideskripsikan bahwa bentuk lingual yang dimunculkan oleh subjek 2 dalam percakapan adalah berupa kata. Hal tersebut dapat diketahui ketika subjek memunculkan bentuk lingual kata kon**l dengan suara pelan. Peneliti tidak mendengar atau menangkap adanya intonasi final yang mengakhiri pemunculan lingual tersebut. Percakapan tersebut menunjukkan bahwa semakin pelan rangsangan yang diberikan, maka subjek juga semakin pelan pula respon lingual yang diucapkan.

\section{b. Bentuk Lingual Latah Berupa Kata Perilaku Latah Ekolalia}

Bentuk lingual latah berupa kata pada perilaku latah ekolalia adalah perilaku latah ini menirukan kata-kata yang diberikan orang lain.

Konteks: Peneliti dan subjek 3 sedang berada di rumah subjek, dimana subjek sedang memasak di dapur. Peneliti mengajak ngobrol subjek dan menawarkan piring kepada subjek.

Tuturan 3:

Pn : Sudah masak sayurnya $\mathrm{Bu}$ ?

$\mathrm{Su}$ : Belum Bang, bentar lagi ni mungkin.

Pn : Ow...saya kira udah masak $\mathrm{Bu}$.

$\mathrm{Su}$ : Belum Bang.

Pn : Ini loh piringnya $\mathrm{Bu}$ (dengan sengaja diam-diam menjatuhkan cangkir ke lantai sehingga membuat kaget subjek)

$\mathrm{Su}$ : Piring, eh piring (sambil mengangkat tangan dan sendok sayur yang informan pegang dan melambailambai).

Berdasarkan data tersebut dapat dideskripsikan bahwa bentuk lingual yang dimunculkan oleh subjek 3 adalah berupa kata. Pemunculan bentuk lingual piring merupakan pengulangan terhadap kata yang diucapkan oleh penulis. Subjek secara spontan mengulang kata tersebut karena subjek merasa terkejut dengan rangsangan berupa lemparan lemparan cangkir yang diberikan secara tiba-tiba.

Konteks : Subjek 2 sedang duduk santai di depan rumah subjek, tidak lama kemudian ada orang lewat menawarkan barang dagangan berupa bantal kepada subjek. Peneliti mengamati subjek di sebelah orang ketiga.

Tuturan 4:

$\mathrm{X} \quad$ : Bantalnya Bu?

$\mathrm{Su} \quad$ : Nggak bang, yang ibu-ibu di situ saja abang tawarkan, rame di situ. 
Pn : (diam-diam membelakangi subjek sambil menyentuh pelan bagian leher subjek)

$\mathrm{Su} \quad$ : Bantal, eh bantal (dengan melihat bantal yang ada di depannya)

Pemunculan lingual bantal pada data tersebut juga dimunculkan dengan intonasi pelan. Hal tersebut terjadi pada saat subjek mendapat rangsangan berupa sentuhan pada leher oleh peneliti. Bentuk lingual kata dapat diketahui ketika subjek memunculkan lingual bantal secara pelan, sehingga penulis tidak menangkap adanya intonasi yang mengikuti pemunculan kata bantal tersebut.

\section{c. Bentuk Lingual Latah Berupa Kata Perilaku Latah Auto Ekolalia}

Bentuk lingual latah berupa kata pada perilaku latah auto ekolalia adalah perilaku latah ini biasanya mengulangi kata-kata yang diucapkannya sendiri.

Konteks : Pada pagi hari ketika peneliti berada di rumah subjek. Subjek berkumpul bersama teman-temannya. Salah seorang teman dari mereka menawarkan sebuah makanan pada subjek 3 .

Tuturan 5:

Pn : Kemana saja $\mathrm{Bu}$, kemaren saya kesisni Ibu tak ada.

$\mathrm{Su}$ : Sibuk Bang, kemaren lagi pigi.

di rumah

X : Masak, kamu kan ada terus

$\mathrm{Su} \quad$ : Beneran Bang, tidak bohong saya

Pn : Oh, ia Bu. Ini ada makanan bu, di makan ya? (dengan sengaja melempar makanan di depan subjek)

Su : Enak, eh enak (sambil melambaikan tangannya ke atas)

Pemunculan lingual enak pada data tersebut adalah berupa kata. Subjek mengucapkan kata tersebut dalam keadaan terkejut ketika menerima rangsangan dari peneliti yang berupa lemparan makanan ke tubuh subjek. Subjek dengan spontan mengulang kata tersebut ketika menerima suatu rangsangan.

\section{Satuan Lingual Latah Berupa Kalimat}

Kalimat adalah satuan sintaksis yang disusun dari konstituen dasar, yang biasa berupa klausa, dilengkapi dengan konjungsi dan disertai dengan intonasi final (Chaer, 2003). Sesungguhnya cara menentukan kalimat bukan dari banyaknya kata melainkan intonasinya. Kalimat yang dimaksud dalam hal ini adalah kalimat yang dimunculkan secara spontan dan dengan intonasi tinggi orang yang mempunyai perilaku latah. Bentuk lingual kalimat yang dimunculkan warga tersebut ada yang berupa proses pengulangan kalimat yang diucapkan orang lain dan pengulangan kalimat yang diucapkan sendiri (hlm. 240).

\section{a. Bentuk Lingual Latah Berupa Kalimat Perilaku Latah Koprolalia.}

Bentuk lingual latah berupa kalimat pada perilaku latah koprolalia adalah perilaku latah ini biasanya mengucapkan kalimat berupa alat kelamin baik laki-laki maupun perempuan.

Konteks : Percakapan ini terjadi antara peneliti dengan subjek 1. Pada sore hari pukul 17.00 subjek saat itu sedang duduk di depan rumah ketika selesai bersih-bersih rumahnya dan kemudian peneliti bermaksud bertanya tentang suami informan. Kemudian peneliti mengajaknya bercakap-cakap.

Tuturan 6:

Pn : Bu, Bapak kemana $\mathrm{Bu}$ ?

$\mathrm{Su} \quad$ : Lagi pergi, tadi ada panggilan katanya (sambil menaruh sapu yang dipegang)

Pn : Oh, ialah Bu. Kalau gitu saya pulang aja bu (dengan sengaja melemparkan kertas ke tubuh subjek).

$\mathrm{Su} \quad$ : Eh it*lmu! (dengan suara lantang) 
Pemunculan bentuk lingual $i t * \operatorname{lmu}$ pada subjek 1 ini merupakan bentuk perilaku latah koprolalia. Pemunculan lingual tersebut muncul ketika subjek merasa kaget dan terkejut karena menerima rangsangan berupa hentakan benda seperti lemparan kertas, sehingga muncul bentuk lingual tersebut dengan suara keras dan jelas. Hal tersebut menunjukkan adanya intonasi final dengan nada naik. Sehingga bentuk lingual $i t^{*} \operatorname{lmu}$ merupakan sebuah kalimat.

Konteks : Percakapan ini terjadi antara peneliti dengan subjek 3 . Subjek saat itu sedang duduk di depan rumahnya pada sore hari pukul 16.00. Kemudian peneliti mengajaknya bercakap-cakap.

Tuturan 7:

$$
\begin{array}{ll}
\mathrm{Pn} & : \text { Santai Bu? } \\
\mathrm{Su} & : \text { Ia Bang. } \\
\mathrm{Pn} & \text { : Nggak kemana-mana }
\end{array}
$$$$
\text { nanti malam } \mathrm{Bu} \text { ? }
$$

$\mathrm{Su} \quad$ : Nggak tahu bang, kayaknya nanti mau main ke rumah saudara.

Pn : Oh, enak ya Bu (tibatiba jatuh bola ke atap rumah subjek dan persis di atas subjek)

$\mathrm{Su} \quad$ : Kon**lmu enak! (dengan suara lantang dan terkejut sambil melambaikan tangan)

Pemunculan bentuk lingual kon**Imu enak pada subjek 3 ini merupakan bentuk perilaku latah koprolalia. Bentuk pemunculan lingual tersebut terjadi ketika subjek terkejut karena menerima rangsangan atau stimulus dengan suara keras. Pada saat subjek terkejut, ia mengucapkan lingual kon**lmu enak! dengan suara keras dengan intonasi tinggi. Intonasi yang teridentifikasi pada saat mengucapkan bentuk-bentuk lingual tersebut adalah intonasi final dengan nada naik seperti sedang menyerukan sesuatu. Bentuk lingual kon**lmu enak dengan intonasi tinggi merupakan sebuah kalimat seruan yang ditandai dengan naiknya suara si penutur dengan perasaan yang kuat atau mendadak sehingga disebut dengan kalimat seruan.

\section{b. Bentuk Lingual Latah Berupa Kalimat Perilaku Latah Ekolalia}

Bentuk lingual latah berupa kalimat pada perilaku latah ekolalia adalah perilaku latah ini menirukan kata dan kalimat yang diberikan orang lain.

Konteks: Subjek sedang membeli sayur disebuah warung (kedai), dan penulis dengan sengaja mendekati subjek hendak membeli sayur juga. Ketika itu dengan sengaja penulis mengambil kerupuk dan dengan sengaja menjatuhkan kerupuk tersebut didepan subjek.

Tuturan 8:

Pn : Mau ngapain $\mathrm{Bu}$, beli sayur Bu?

$\mathrm{Su} \quad$ : Ia Bang, ini mau beli sayur.

Pn : Kerupuknya jatuh (sambil mengambil kerupuk dan dengan sengaja menjatuhkannya di depan subjek)

Su : Kerupuknya jatuh! Eh kerupuknya jatuh! (terkejut dan menunjuk ke arah kerupuk yang jatuh)

Berdasarkan data di atas, dapat diketahui bahwa bentuk lingual yang dimunculkan oleh subjek berupa pengulangan kalimat yang diucapkan penulis, yaitu kerupuknya jatuh! Subjek mengulang kalimat tersebut karena merasa terkejut dan kemudian dengan sengaja mengulangnya lagi. Identifikasi kalimat tersebut karena subjek mengucapkan dengan disertai adanya intonasi final yang mengakhiri pemunculan lingual tersebut.

\section{c. Bentuk Lingual Latah Berupa Kalimat Perilaku Latah Auto Ekolalia.}

Pemunculan lingual kalimat juga ditemukan dalam perilaku latah auto ekolalia. Perilaku latah ekolalia merupakan perilaku 
latah ini biasanya mengulangi kata-kata yang diucapkannya sendiri.

Konteks : Pada sore hari pukul 15.00 WIB, subjek 3 ke rumah nenek penulis (yang sudah penulis anggap nenek penulis yang rumahnya tidak jauh dari rumah subjek) untuk membagikan undangan. Ketika subjek berjalan di depan rumah penulis, tibatiba teman subjek mengejutkan dari belakang.

Tuturan 9:

Su : Kak, ini ada undangan dari rumah untuk minggu depan.

Pn : Untuk acara apa Bu?

$\mathrm{X} \quad$ : Heh ... (dengan tibatiba mengejutkan subjek dengan cara memegang pinggang subjek 3 dari belakang)

$\mathrm{Su} \quad$ : Ibunya gila, eh ibunya gila! (sambil menggerakkan tangan dan menutup mulut dengan kedua tangannya).

Pemunculan bentuk lingual ibunya gila tersebut merupakan pengulangan kalimat yang diucapkan sendiri oleh subjek. Berdasarkan data tersebut, dapat dideskripsikan bahwa bentuk lingual yang dimunculkan oleh subjek 3 adalah berupa kalimat. subjek secara spontan mengulang kalimat tersebut ketika subjek terkejut saat menerima rangsangan. Bentuk lingual tersebut dapat diidentifikasi sebagai bentuk kalimat, karena ketika subjek dalam memunculkan lingual tersebut dengan suara keras seolah-olah sedang menyerukan lingual tersebut. Pemunculan lingual ibunya gila dengan suara keras tersebut diidentifikasi sebagai kalimat karena terdapat intonasi dengan nada naik yang mengakhirinya.

\section{d. Bentuk Lingual Latah Berupa Kalimat Perilaku Latah Automatic Obidience}

Bentuk lingual latah berupa kalimat pada perilaku latah automatic obidience adalah perilaku latah ini biasanya melaksanakan perintah secara spontan pada saat terkejut.

Konteks : Pada pagi hari ketika subjek selesai berbelanja di sebuah toko (kedai). Penulis lalu menghadang subjek di jalan, lalu menyuruh subjek 2 untuk duduk di hadapan peneliti.

Tuturan 10:

$\mathrm{Pn} \quad$ : Bu, dari mana $\mathrm{Bu}$ ?

$\mathrm{Su} \quad$ : Ini, dari warung tadi

Bang beli untuk masak nanti.

Pn : Belanja tadi Bu, jongkok bu! (dengan suara keras dan menyuruh subjek untuk jongkok)

$\mathrm{Su} \quad$ : jongkok bu! jongkok! (dengan cepat dan terkejut segera informan 2 melakukan apa yang diperintahkan dan mengulangi kata yang diucapkan peneliti).

Berdasarkan data tersebut, dapat dideskripsikan bahwa bentuk lingual yang diucapkan peneliti kemudian diulangi oleh subjek tersebut adalah berupa kalimat. Hal tersebut dapat diidentifikasi sebagai kalimat, karena subjek dalam memunculkan lingual tersebut sangat cepat dan dengan suara keras atau lantang menirukan kata yang diberikan peneliti.

\section{Fungsi Bahasa Latah}

Pada bagian fungsi bahasa latah ini, pendapat para ahli dipaparkan oleh penulis tentang fungsi bahasa yang dikaitkan dengan kondisi dan lingual yang diucapakan oleh subjek.

a. Santoso, dkk (2004) berpendapat bahwa bahasa sebagai alat komunikasi memiliki: (1) Fungis informasi, yaitu untuk menyampaikan informasi timbal balik antar anggota 
keluarga atau anggota masyarakat. (2) Fungsi ekspresi diri, yaitu untuk menyalurkan perasaan, sikap, gagasan, emosi atau tekanan-tekanan perasaan. Ini dapat menyatakan eksistensi diri, membebaskan diri dari tekanan emosi dan untuk menarik perhatian orang lain. (3) Fungsi adaptasi dan integrasi, yaitu untuk menyesuaikan dan membaurkan diri dengan orang lain.

(4) Fungsi kontrol sosial, yaitu untuk mempengaruhi sikap dan pendapat orang lain.

Hal ini dapat dilihat dari dialog yang dilakukan oleh peneliti dengan subjek 1

Konteks: Percakapan ini terjadi antara peneliti, X dengan subjek 1 pada pukul 10.30 WIB. Ketika itu peneliti bertemu (berpapasan) dengan subjek dan $\mathrm{X}$ di tengah jalan, sedang subjek dan $\mathrm{X}$ Tuturan 11 kembali ke rumahnya.

$\begin{aligned} \text { Bu? } & \text { : Ibu, dari mana tadi } \\ \text { Su } & \text { : Dari simpang limun } \\ \text { adi Bang. } & \\ \mathrm{Pn} & \text { : Belanja ya Bu? } \\ \mathrm{Su} & \text { : Ia Bang. } \\ \mathrm{Pn} & : \text { (dengan memberikan } \\ & \text { bahasa isyarat kepada } \\ & \mathrm{X} \text { untuk mengejutkan } \\ & \text { subjek) }\end{aligned}$

$\begin{array}{rcr}\mathrm{X} & : \quad \mathrm{Bu}, \quad \text { (dengan } \\ \text { mengguit pinggang } \\ \text { belakang) }\end{array}$

Su : Kon $* * l$, eh kon $* * l$.

(dengan menutup mulutnya)

Berdasarkan data tuturan 11 tersebut dapat dideskripsikan bahwa bentuk lingual yang dimunculkan oleh subjek dalam percakapan adalah berupa ucapan yang tabu di kalangan masyarakat. Hal tersebut dapat diketahui ketika X mengagetkan subjek, lalu subjek memunculkan bentuk lingual kata "kon**l", pada jam 10.30 pagi. Dari percakapan tersebut menunjukkan bahwa subjek mengucapkan kata kotor tersebut karena dalam keadaan terkejut atau dikejutkan oleh orang lain sehingga subjek dengan kondisi di luar kesadarannya mengucapkan kata tersebut. Dari uraian pendapat Santoso dkk (2004) bahwa fungsi bahasa yang termasuk pada tuturan yang di ucapkan oleh subjek tersebut merupakan bagian dari fungsi ekspresi diri, yaitu untuk menyalurkan perasaan, sikap, gagasan, emosi atau tekanan-tekanan perasaan. Ini dapat menyatakan eksistensi diri, membebasan diri dari tekanan emosi dan untuk menarik perhatian orang lain. Hal ini ditunjukkan oleh subjek ketika peneliti bertanya bagaiman perasaan subjek ketika sudah mengucapkan kata tersebut, lalu subjek berkata "saya senang Bang”. Berarti ini menunjukkan adanya penyaluran sikap, emosi atau tekanan perasaan yang dialami subjek. Adanya perhatian lebih yang dilakukan oleh orang lain terhadap subjek membuat subjek merasa senang atasa apa yang dilakukannya melalui ucapan-ucapan yang dia ucapakan. Hal ini pernah suatu saat subjek ditanya oleh peneliti tentang bagaimana perasaannya ketiak dia melihat orang yang ada di sekitarnya senang dan tertawa melihat perilakunya, lalu subjek berkata "terkadang senang bang orang itu tertawa, tapi kadang capek juga bang".

Dari pertanyaan yang dilontarkan oleh peneliti, dan jawaban dari subjek menunjukkan bahwa perilaku latah subjek dengan mengucapkan kata-kata kotor ketika dikagetkan oleh orang lain merupakan fungsi bahasa yang dikategorikan pada fungsi ekpresi diri.

b. Keraf (1990) menyatakan bahwa bahasa memiliki fungsi sebagai alat komunikasi, alat untuk menyatakan ekspresi diri, alat untuk mengadakan integrasi dan adaptasi sosial, dan alat untuk mengadakan control sosial (hlm.3-6).

Berbicara tentang perwujudan bahasa tidak lepas dari faktor-faktor yang menyebabkan munculnya kata dan kalimat. Kata-kata maupun kalimatkalimat yang muncul didasarkan atas fungsi bahasa. Fungsi-fungsi bahasa didasarkan pada fungsi bahasa sebagai sarana pengungkapan perasaan, selain sebagai tujuan 
komunikasi. Perbedaan ini dapat berupa perbedaan bentuk tuturan dan dapat juga perbedaan maksud tuturan berkaitan dengan faktor-faktor penyebab munculnya tuturan.

c. Mustakim (1994) mengemukakan bahwa bahasa juga bisa sebagai alat untuk mengekspresikan segala sesuatu yang mengendap dalam dunia batin seseorang, baik berupa gagasan, pikiran, perasaan, maupun pengalaman yang dimilikinya. Dalam hal ini, bahasa digunakan untuk menyatakan keberadaan dan eksistensi seseorang, dengan demikian bahasa bukan saja untuk mencerminkan gagasan atau pikiran, melainkan juga mencerminkan perasaan dan perilaku seseorang (hlm. 4).

Konteks : Percakapan ini terjadi antara peneliti dengan subjek 2 pada pukul 18.30 WIB. Ketika itu peneliti datang ke rumah subjek lalu duduk di teras rumah subjek sembari bercakap cakap dengan subjek.

Tuturan 12

Pn : Bu, apa itu di atas tu

$\mathrm{Bu}$ ?

$\mathrm{Su} \quad$ : Dimana?

Pn : Itu di atas Bu (Subjek pun melihat ke atas, lalu Peneliti mengagetkan Subjek dengan mengatakan "ha" sambil mengguit tangan Subjek

$\mathrm{Su} \quad:$ It $* l$, eh $i t^{*} l$. (subjek melambaikan

tangannya ke atas lalu memegang mulutnya)

Pn : Ah, Abang buat kaget

aja.

Berdasarkan data tuturan 12 tersebut dapat dideskripsikan bahwa bentuk lingual yang dimunculkan oleh subjek dalam percakapan adalah berupa ucapan yang tabu di kalangan masyarakat. Hal tersebut dapat diketahui ketika peneliti mengagetkan subjek, lalu subjek memunculkan bentuk lingual kata " $i t^{*} l$ ", pada jam 10.30 pagi. Dari percakapan tersebut menunjukkan bahwa subjek mengucapkan kata " $i t * l$ " tersebut karena dalam keadaan terkejut atau dikejutkan oleh peneliti sehingga subjek dengan kondisi di luar kesadarannya mengucapkan kata tersebut. Dari uraian pendapat Keraf (1990:36) bahwa fungsi bahasa yang termasuk pada tuturan yang di ucapkan oleh subjek tersebut merupakan bagian dari fungsi alat komunikasi, yaitu untuk menyampaikan segala sesuatu yang terucap dari alat indera (mulut) untuk dipahami orang lain atau lawan bicara (hlm. 3-6). Hal ini juga berlaku kepada subjek yang mengucapkan kata tabu tersebut kepada peneliti yang mengagetkannya.

Kemudian juga menurut Mustakim (1994) bahwa fungsi bahasa adalah alat untuk mengekspresikan segala sesuatu yang mengendap dalam dunia batin seseorang, baik berupa gagasan, pikiran, perasaan, maupun pengalaman yang dimilikinya. Termasuk pada tuturan subjek ini adalah menyalurkan perasaan, sikap, gagasan, emosi atau tekanan-tekanan perasaan. Ini dapat menyatakan eksistensi diri, membebasan diri dari tekanan emosi dan untuk menarik perhatian orang lain (hlm. 4). Hal ini ditunjukkan oleh subjek ketika peneliti bertanya bagaiman perasaan subjek ketika sudah mengucapkan kata tersebut, lalu subjek berkata "saya senang Bang". Berarti ini menunjukkan adanya penyaluran sikap, emosi atau tekanan perasaan yang dialami subjek. Adanya perhatian lebih yang dilakukan oleh orang lain terhadap subjek membuat subjek merasa senang atasa apa yang dilakukannya melalui ucapan-ucapan yang dia ucapakan. Hal ini pernah suatu saat subjek ditanya oleh peneliti tentang bagaimana perasaannya ketika dia melihat orang yang ada di sekitarnya senang dan tertawa melihat perilakunya, lalu subjek berkata "Kadang enak Bang, bisa membuat orang tertawa tapi seringan tidak enak Bang, capek". 
Dari pertanyaan yang dilontarkan oleh peneliti, dan jawaban dari subjek menunjukkan bahwa perilaku latah subjek dengan mengucapkan kata-kata kotor ketika dikagetkan oleh orang lain merupakan fungsi bahasa yang dikategorikan pada fungsi ekpresi diri.

d. Hallyday (1975), bahwa bahasa itu memiliki 7 fungsi:

Instrumental : language used to fulfill a need on the part of the speaker. Directly concerned with obtaining food, drink and comport.

Regulatory : Language used to influence the behavior of others. Concerned with persuading/command ing/requesting other people to do things yo want.

Interactional : Language used to develop social relationships and ease the process of interaction.

Concerned with the phatic dimension of talk.

Personal : Language used to express the personal preferences and identity of the speaker.

Representational: language used to exchange information.

Concerned with relaying requesting information.

Heuristic : Language used to learn and explore the environment.

Imaginative : language used to explore the imagination.

Konteks : Percakapan ini terjadi antara X, peneliti dengan subjek 3 . Subjek saat itu sedang berbelanja di warung (kedai) yang tidak jauh dari rumahnya pada pagi hari pukul 08.00 WIB. Lalu $\mathrm{X}$ mengagetkan subjek.

Tuturan 13

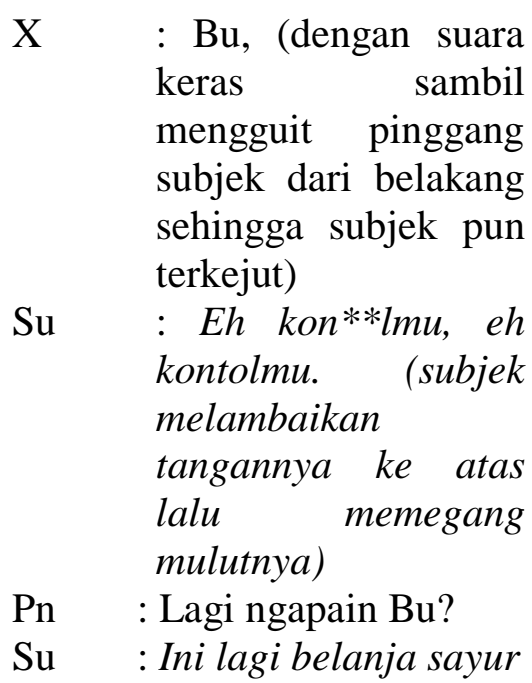

Konteks : Percakapan ini terjadi antara Peneliti dengan subjek 3. Subjek saat itu sedang berjalan menuju rumah tetangganya pada pagi hari pukul 10.00 WIB. Lalu peneliti diam-diam menghampiri Subjek dari belakng, lalu mengagetkannya.

Tuturan 14

$\mathrm{X} \quad \mathrm{Bu}$, (dengan suara pelan sambil mengguit pinggang subjek dari belakang sehingga subjek pun terkejut)

Su : Eh gila, eh gila. (dengan memegang mulutnya)

Pn : Mau kemana Bu?

$\mathrm{Su} \quad$ : Ini mau ke rumah itu bang (dengan menunjuk rumah yang akan Dia tuju)

Berdasarkan data tuturan 13 dan 14 tersebut dapat dideskripsikan bahwa bentuk lingual yang dimunculkan oleh subjek dalam percakapan adalah berupa ucapan yang tabu di kalangan masyarakat. Hal tersebut dapat diketahui ketika peneliti mengagetkan subjek, lalu subjek memunculkan bentuk lingual kata "kon**l" dan "gila", pada jam 08.00 dan 10.00 WIB. Pagi hari. Dari percakapan 
tersebut menunjukkan bahwa subjek mengucapkan kata jorok tersebut karena dalam keadaan terkejut atau dikejutkan oleh peneliti sehingga subjek dengan kondisi di luar kesadarannya mengucapkan kata-kata tersebut.

Dari uraian pendapat Halliday (1975) bahwa fungsi bahasa itu ada tujuh, dan yang termasuk pada tuturan yang di ucapkan oleh subjek tersebut merupakan baagian dari fungsi interaksi (the interactional function) yaitu memantapkan ketahanan dan kelangsungan komunikasi sosial dan personal (the personal function), yaitu memberi kesempatan kepada seseorang pembicara mengekspresikan perasaan, emosi pribadi, serta reaksi-reaksi yang mendalam. Hal ini juga berlaku kepada subjek yang mengucapkan kata tabu tersebut kepada peneliti yang mengagetkannya.

Termasuk pada tuturan subjek ini adalah menyalurkan perasaan, emosi atau tekanan-tekanan perasaan. Ini dapat menyatakan eksistensi diri, membebaskan diri dari tekanan emosi dan untuk menarik perhatian orang lain. Sehingga ketika orang lain memberikan stimulus kepada subjek berupa sentuhan atau sesuatu yang membuat subjek menjadi kaget, maka subjekpun memberikan respon berupa kata-kata yang keluar dari mulut subjek dalam keadaan tidak sadar. Hal ini ditunjukkan oleh subjek ketika peneliti mengguit pinggang subjek, lalu subjek dengan kagetnya mengucapkan "gila". Kemudian peneliti bertanya bagaimana perasaan subjek ketika sudah mengucapkan kata tersebut, lalu subjek berkata "saya senang Bang”. Berarti ini menunjukkan adanya penyaluran sikap, emosi atau tekanan perasaan yang dialami subjek. Adanya perhatian lebih yang dilakukan oleh orang lain terhadap subjek membuat subjek merasa senang atasa apa yang dilakukannya melalui ucapan-ucapan yang dia ucapakan. Hal ini

\section{DAFTAR PUSTAKA}

Arikunto, S. (1993). Manajemen Penelitian. Jakarta: Rineka Cipta pernah suatu saat subjek ditanya oleh peneliti tentang bagaimana perasaannya ketiak dia melihat orang yang ada di sekitarnya senang dan tertawa melihat perilakunya, lalu subjek berkata "terkadang senang Bang orang itu tertawa, tapi kadang capek juga Bang".

Dari pertanyaan yang dilontarkan oleh peneliti, dan jawaban dari subjek menunjukkan bahwa perilaku latah subjek dengan mengucapkan kata-kata kotor ketika dikagetkan oleh orang lain merupakan fungsi bahasa yang dikategorikan pada fungsi interaksi dan personal.

\section{SIMPULAN}

Penelitian mengenai bahasa latah pada beberap warga Jalan Garu III Medan Amplas, Kota Medan ini diperoleh suatu deskripsi pemunculan lingual latah berupa kata dan kalimat. Pemunculan lingual latah tersebut berkaitan erat dengan jenis-jenis perilaku latah yang ada yaitu, (1) ekolalia, (2) koprolalia, (3) auto ekolalia, da (4) automatic obedience. Bentuk lingual latah yang muncul tersebut adalah lingual berupa kata pada perilaku latah ekolalia, koprolalia, auto ekolalia dan auto ekolalia, dan lingual berupa kalimat pada perilaku latah ekolalia, koprolalia, auto ekolalia dan automatic obidience.

Fungsi bahasa yang dikemukakan oleh para ahli yang dikaitkan dengan bahasa orang latah pada penelitian ini adalah (1) fungsi ekspresi diri, yaitu orang latah tersebut menyalurkan perasaan, sikap, gagasan, emosi atau tekanan-tekanan perasaan. (2) fungsi interaksi (the interactional function), yaitu memantapkan ketahanan dan kelangsungan komunikasi sosial, dan (3) fungsi personal (the personal function), yaitu member kesempatan kepada orang latah tersebut mengekspresikan perasaan, emosi pribadi, serta reaksi-reaksi yang mendalam.

Chaer, A. (2003). Psikolinguistik Kajian

Teoretik. Jakarta: Rineka Cipta

Chaer, A. (2009). Psikolinguistik Kajian

Teoretik. Jakarta: Rineka Cipta 
Dardjowidjojo, S. (2005). Psikolinguistik Pengantar Pemahaman Bahasa Manusia. Jakarta: Yayasan Obor Indonesia

Finoza, Lamuddin. (2002). Komposisi Bahasa Indonesia. Jakarta: Diksi Insan Mulia

Hariyanto, Bambang., Wibisono, bambang., Kusnadi. 2014. Perilaku Berbahasa Latah Warga Desa Jatigono Kecamatan Kunir kabupaten Lumajang Sebuah Kajian Psikolinguistik. Volume 2 (1). Publika Budaya

Halliday, M.A.K. (1975). Learning How to Mean: Exploration in Development of Language. London: Edward Arnold

Keraf, G. (1997). Komposisi. Jakarta: Nusa Indah.
Moeloeng, L, J. (2005). Metode Penelitian Kualitatif. Bandung. Remaja Rosdakarya.

Mustakin. (1994). Membina Kemampuan Berbahasa, Panduan ke Arah Kemahiran Berbahasa. Jakarta: Gramedia Pustaka Utama.

Pamungkas, S. (1998). "Bahasa Latah (Suatu Tinjauan Psikolinguistik pada Beberapa Masyarakat latah di Jember)". Tidak Dipublikasikan. Skripsi Jember: Fakultas Sastra Universitas Jember.

Patede, M. (1998). Aspek-Aspek Psikolinguistik. Flores: Nusa Indah

Santoso, dkk. (2013). Materi dan Pembelajaran Bahasa Indonesia. (Banten: Universitas Terbuka).

Sudaryanto. (1993). Metode dan Teknik Analisis Bahasa. Yogyakarta: Duta Wacana University Press. 